\title{
Padrões de crescimento e desenvolvimentismo: uma perspectiva keynesiano-institucionalista
}

Growth regimes and developmentalism: a Keynesian-Institutionalist approach

\begin{abstract}
Considering the controversy between new-developmentalism and socialdevelopmentalism approaches, this paper aims at, on the one hand, showing that both approaches can be reconciled, and, on the other hand, proposing a KeynesianInstitutionalist strategy for assuring a sustainable economic growth for the Brazilian economy combined with monetary stability, fiscal and external equilibria and social inclusion.
\end{abstract}

\section{Keywords}

new developmentalism; social developmentalism; keynesian-institucionalist approach.

JEL Codes B52; E2; E12.

\author{
Fernando Ferrari Filho \\ Universidade Federal do Rio Grande do Sul \\ Luiz Fernando de Paula \\ Universidade do Estado do Rio de Janeiro
}

\section{Resumo}

Tendo como ponto de partida a controvérsia entre as proposições novo-desenvolvimentista e social- desenvolvimentista, o artigo objetiva mostrar que ambas abordagens podem ser conciliáveis, bem como propõe uma estratégia keynesiano-institucionalista para a economia brasileira que seja capaz de assegurar crescimento econômico sustentável, estabilidade monetária, equilibrios fiscal e externo e inclusão social.

\section{Palavras-chave}

novo-desenvolvimentismo; social-desenvolvimentismo; abordagem keynesiana-institucionalista.

Códigos JEL B52; E2; E12. 


\section{Introdução}

Desde o início dos anos 2000, a performance da economia brasileira, sob a ótica do Produto Interno Bruto (PIB), tem apresentado melhores resultados do que as décadas anteriores, denominadas "perdidas": entre 2000 e 2014, a taxa média do PIB foi da ordem de 3,3\%. A despeito desse período ter apresentado crescimento médio do PIB mais auspicioso, a atividade econômica continuou sendo caracterizada por um processo de crescimento à la stop-and-go e, além do mais, nos últimos anos, a taxa de crescimento desacelerou-se significativamente: entre 2011 e 2014 o PIB cresceu, em média, 2,2\% ao ano. Isso tem levado a uma discussão a respeito das causas da desaceleração econômica recente, estando ela relacionada a fatores conjunturais ou a fatores estruturais. Nosso entendimento é que a desaceleração é resultado de uma combinação desses dois conjuntos de fatores.

Ademais, a fraca performance do PIB no período 2011-2014 nos remete não somente à questão da necessidade do crescimento econômico mais robusto e sustentável estar no centro da discussão, mas principalmente à discussão a respeito do fato de que esse baixo crescimento econômico estaria relacionado - por hipótese - aos limites da atual política redistributiva, uma vez que os setores industriais estariam se defrontando em tese com um fenômeno de profit squeeze, causado pela combinação câmbio apreciado e salário real acima da produtividade do trabalho que acabaria por comprimir a margem de lucro da indústria.

É importante ressaltar que, a despeito dessa discussão, é indubitável que houve avanços significativos desde a última década em termos de redução da pobreza no país e da melhoria na distribuição de renda, em parte relacionado a um aumento real no salário mínimo, como atestado pela gradual e persistente diminuição no Índice de Gini. ${ }^{1}$ A sustentabilidade de um crescimento puxado pelo salário (wage-ledgrowth) é uma questão em aberto.

De fato, considerando que o cenário internacional não parece favorecer, como ocorreu no período 2002-2007, a economia brasileira, uma questão que emerge naturalmente é se é possível compatibilizar um crescimento econômico mais robusto e sustentável com uma agenda de inclusão social e redistribuição de renda. Este artigo sustentará que isso é possível dentro 
de certos limites. E mais, entende-se que a própria continuidade do processo de redistribuição de renda depende de um crescimento mais dinâmico da economia brasileira.

O debate brasileiro atual, apesar de outras nuances, parece sugerir a polaridade entre duas estratégias de desenvolvimento ${ }^{2}$ - novo-desenvolvimentismo e social-desenvolvimentismo -, que poderiam ser, à primeira vista, entendidas como opostas: uma estratégia de crescimento puxada pelo mercado interno e outra puxada pelas exportações. $\bigcirc$ objetivo deste artigo é analisar tais estratégias de crescimento à luz do boom de crescimento dos anos 2000 e a recente desaceleração econômica, e, em particular, mostrar que essas podem ser, em algum grau, conciliáveis, ainda que em determinados momentos o driver seja o consumo interno, e, em outros, as exportações líquidas. Por outro lado, é apresentada uma proposta keynesiano-institucionalista, alicerçada em um conjunto de políticas econômicas que visam assegurar estabilidade macroeconômica, entendida como inflação sob controle, equilíbrios fiscal e externo, crescimento sustentável e inclusão social e distribuição de renda para o Brasil.

Para tanto, o artigo está dividido em quatro seções, além desta introdução: a seção 2 tece algumas considerações sobre regimes de crescimento. A seção 3, por sua vez, discute as estratégias de desenvolvimento no Brasil conhecidas como novo-desenvolvimentismo e social-desenvolvimentismo. A seção 4 analisa o boom de crescimento pós-2003 e as causas da desaceleração econômica recente no Brasil, ao passo quea seção 5 apresenta uma proposição keynesiano-institucionalista para a economia brasileira. Por fim, a seção 6 conclui o artigo.

\section{Breves considerações sobre regimes e padrão de crescimento econômico}

Uma forma bastante difundida na heterodoxia de fazer distinção entre padrões de crescimento, com base no trabalho seminal de Bhaduri e Marglin (1990), é dividir os regimes de crescimento em wage-led growth e profit-led growth: se a mudança na distribuição funcional da renda em prol dos salários gera efeito positivo sobre o crescimento econômico, então o regime

2 Para uma discussão detalhada sobre os vários significados e o conceito de desenvolvimentismo, ver: Fonseca (2014). 
se define como wage-led growth - crescimento conduzido pelos salários; e se, alternativamente, uma mudança em prol dos lucros resulta em um aumento no crescimento econômico, então o regime se define como profit-led growth - crescimento conduzido pelo lucro.

Seguindo a tradição neokaleckiana de modelos de crescimento e distribuição de renda, no wage-led growth o aumento da participação dos salários na renda, em função de maiores gastos de consumo graças a maiores salários reais, resulta em maiores taxas de utilização e maior acumulação de capital, dada a alta sensibilidade do investimento ao consumo agregado; por sua vez, no profit-led growth, em razão da alta sensibilidade do investimento à taxa de lucro, maior participação dos lucros na renda gera maior utilização de capacidade produtiva e logo maior produção, ou seja, nesse caso as mudanças salariais são vistas pelos seus efeitos sobre a oferta, de tal forma que a redistribuição da renda em detrimento das rendas de trabalho estimula os gastos de investimento contrapondo ao efeito depressivo de mais baixo consumo sobre a demanda agregada. ${ }^{3}$

Lavoie e Stockhammer (2012) sustentam que uma economia está sob um regime profit-led growth ou wage-led growth dependendo da sua estrutura econômica, isto é, da distribuição de renda existente e do grau de abertura econômica do país (comercial e financeira). Além do mais, os autores argumentam que outros componentes comportamentais devem ser levados em consideração para determinar o regime de crescimento: a propensão a consumir dos vários estratos de renda, a sensibilidade dos empresários a mudanças nas vendas ou nas margens de lucro, as mudanças na taxa de câmbio, a demanda externa ea participação das variáveis da demanda agregada (consumo, investimento, gastos do governo e exportações líquidas). No que diz respeito ao setor externo, estruturas econômicas com pequenos diferenciais na propensão a consumir, investimento altamente sensível à lucratividade e economias muito abertas, com alta elasticidade-preço das exportações e alta elasticidade-renda das importações, tendem a se caracterizar como profit-led growth; ${ }^{4}$ e, contrariamente, estruturas econômicas com propensão a consumir diferenciadas entre salários e lucros e

\section{Para uma breve resenha, ver: Hein (2012).}

4 Neste caso, a diminuição nos salários e nos benefícios dos trabalhadores propiciaria maiores margens de lucro que induziriam os empresários a aumentar a capacidade produtiva, sendo que os trabalhadores se beneficiariam eventualmente de maiores taxas de emprego e maior poder de compra puxado pelo crescimento na produção. 
investimento não sensível à lucratividade (e parâmetro do acelerador elevado) tendem a se caracterizar com wage-led growth. Outros fatores que ajudam a definir o regime de crescimento são a política econômica adotada (monetária, fiscal e cambial), mudanças na demanda mundial, nos preços de commodities, etc.

Blecker (1989) destaca que um crescimento wage-led seria bem-sucedido somente se a economia é relativamente fechada para o comércio externo, na medida em que tem baixa elasticidade-preço de exportações e importações, baixa elasticidade renda das importações e pequeno coeficiente de importação. Por sua vez, as economias altamente vulneráveis à concorrência internacional e cujas exportações e importações são relativamente sensíveis aos preços têm maior probabilidade de apresentar um regime de crescimento do tipo profit-led. Nesse tipo de regime, uma desvalorização da taxa de câmbio real resultará em aumento de utilização da capacidade produtiva e da taxa de investimento, uma vez que tal desvalorização implicará uma redução do salário real, permitindo ampliar a margem de lucro das empresas, com efeitos positivos sobre os seus investimentos planejados.

Cabe ressaltar que o chamado export-led growth, regime de crescimento sugerido com base na tradição kaldoriana, pode ser visto como uma variante do regime profit-led growth, é o export-led growth, em situações em que salários e demanda doméstica são comprimidos, e as exportações são estimuladas via política cambial e/ou política industrial (Hein, 2003, p.588). Portanto, esse deve ser visto com um regime de crescimento no qual a dinâmica do crescimento é determinada primordialmente pela evolução das exportações líquidas, que gera aumento no coeficiente de exportações (e depois sua razoável manutenção em determinado e elevado patamar) em dada economia. Seguindo a tradição kaldoriana, o export-led growth é uma situação em que as exportações líquidas desempenham papel central na determinação do produto; mais especificamente, com preços fixos dos produtos e elasticidade-preço infinita de oferta por parte dos produtores, expansão autônoma das exportações, que gera um processo multiplicador de renda, ocasionando um produto maior, o que, por sua vez,resulta em aumento da produtividade na presença de efeitos Verdoorn. ${ }^{5}$ Em particu5 Um dos problemas que têm sido levantados em relação à estratégia export-led growth é que o crescimento das exportações líquidas se faz em detrimento do resto do mundo, pois, dado que todos os países não podem adotar simultaneamente tal estratégia (quem compraria de quem?), estaria, assim, seguindo uma política de enfraquecimento do vizinho (beggar-thy-neighbour policy). Neste sentido, Hein (2012) sustenta que tal estratégia pode ser bem- 
lar, no caso de economias emergentes em processo de desenvolvimento, o crescimento das exportações de maior valor agregado - o setor manufatureiro é visto como responsável por gerar externalidades de aprendizado, economias de escala e/ou maior escopo para o progresso tecnológico, podendo motivar um processo learning by-exporting - abre espaço para a economia crescer sem enfrentar em constrangimentos do balanço de pagamentos (Razmi, 2013).

Em geral, a variável que dinamiza o crescimento, qual seja, salários e/ ou exportação - aqui denominada de variável desencadeadora -, não deve ser entendida como sua responsável única: ela deve se articular com as outras componentes da demanda agregada, em especial o investimento, público e privado. A articulação entre a variável desencadeadora e as demais configura o que Ferrari Filho e Fonseca (2015) denominam de padrão de crescimento. Este, todavia, embora possa aparecer embrionariamente sem intenção definida pelos policymakers, geralmente não é automático nem se reproduz espontaneamente: exige uma política econômica deliberada para sua viabilização. Entende-se aqui por política econômica não somente as políticas tidas como de estabilização ou utilizadas com vistas a obter taxas desejáveis de crescimento e inflação ao longo do ciclo, tais como as políticas monetárias, cambiais e fiscais, mas as políticas fins (interventoras de forma horizontal ou vertical em segmentos ou setores, como as políticas industrial, agrária e tecnológica, dentre outras) e as políticas estrutural-institucionais. Igualmente, políticas sociais e de renda (salário mínimo, programa de renda mínima, fortalecimento de barganha coletiva, etc.) também afetam o padrão de crescimento.

Isso posto, fica assentado que um padrão de crescimento não significa apenas "eleger" a variável desencadeadora; essa somente terá êxito em alavancar o crescimento se for capaz de garantir a articulação com as demais. Neste sentido, a contribuição de Keynes (2007) sobre a relevância do investimento na determinação da demanda agregada é fundamental. Se ele for capaz de responder positivamente a aumentos salariais, configura-se a possibilidade de reprodução de uma trajetória exitosa wage-led growth. Em uma economia aberta e mais globalizada, se o investimento responder positivamente ao crescimento das exportações, configura-se a possibilidade de reprodução de uma trajetória exitosa export-led growth. Todavia, a hipó- 
tese que perpassa as considerações a seguir é que seja qual for o padrão de crescimento, ele somente poderá reproduzir-se e configurar uma trajetória exitosa caso, respectivamente, o crescimento dos salários e das exportações seja capaz de induzir maior perspectiva de lucro e, por conseguinte, elevar o nível de investimento.

Nesse particular, conforme Keynes (2007, capítulo 12), em contexto nos quais as tomadas de decisão de investimento têm como fundamento expectativas formadas em bases frágeis sobre o comportamento futuro da demanda, grau de confiança e convenções, mais amplamente, instituições, são fundamentais para que o estado de ânimo (animal spirits) do empresário seja observado. Nas palavras de Keynes (2007, p. 161), parte substancial das tomadas de decisão "pode ser somente tomada como resultado do animal spirits". O que condiciona, favoravelmente, o animal spirits? Expectativas otimistas, naturezas política e social, instituições e política econômica, dentre outras variáveis. Em suma, a articulação entre a variável desencadeadora e os demais determinantes da demanda agregada deve ocupar lugar destacado na formulação da política econômica para viabilizar o padrão de crescimento.

Em decorrência, esse é um dos grandes desafios dos policymakers, uma vez que, em parte, tal articulação não depende apenas deles, posto que também se deixe impactar por variáveis tidas como "exógenas" a seu âmbito de atuação, como as de natureza política, as restrições externas e as alterações estruturais no padrão tecnológico vigente. ${ }^{6}$ Por isso, a opção por um padrão não resulta de "simples escolha": há variáveis que contribuem para facilitar ou restringir sua viabilidade, configurando uma diferença entre a sua formulação (típica-ideal ou "modelo") e a realidade fática de sua implantação. Acrescente-se ainda que, como já destacado, devem ser levadas em consideração as características estruturais da economia e seu estágio de desenvolvimento.

Normalmente se associa como ponto forte do padrão export-led growth sua capacidade de minimizar uma das restrições mais frequentes ao crescimento de países com moeda internacionalmente inconversível: a atinente ao equilíbrio do balanço de pagamentos, cuja persistência dessa restrição impõe frequentes desacelerações, inflação (com as desvalorizações cam-

6 Nesse aspecto, parece-nos apropriada a preocupação de Bielschowsky (2012) de, ao propor um modelo de desenvolvimento semelhante ao padrão wage-led growth (o qual denomina bens de consumo de massa), procurar articulá-lo com a expansão do investimento em outros setores ou "frentes de expansão", no caso recursos naturais e infraestrutura, os quais deveriam ser alavancados pela inovação tecnológica e pela reativação de encadeamentos produtivos tradicionais. 
biais então emergencialmente utilizadas) e endividamento externo. Indo nessa direção, economias periféricas, face às características de sua estrutura produtiva pouco diversificada, têm seu crescimento limitado pela chamada Lei de Thirlwall, segundo a qual a baixa elasticidade-renda dos produtos de menor valor agregado exportado por países em desenvolvimento, comparada com a maior elasticidade-renda das importações produzidas pelos países desenvolvidos, gera déficits de caráter estrutural no balanço de pagamentos nos primeiros. Esses déficits crescentes podem resultar em um obstáculo significativo ao crescimento econômico em países em desenvolvimento, uma vez que a manutenção de um déficit em conta-corrente não explosivo requer que a taxa doméstica de crescimento seja mantida abaixo da taxa de crescimento mundial para que as importações e as exportações se equilibrem (Thirlwall, 2002).

Por sua vez, o padrão wage-led growth apresenta a vantagem de abrir espaço para melhor distribuição de renda, já que se propõe a criar condições para uma relação "cooperativa" entre salários e lucros, em que crescimento dos salários é fator indutor dos investimentos e dos lucros. Não necessariamente, nesse padrão é crescente e contínua a participação dos salários na renda, nem poderia ser essa a sua principal característica ex-post, a qual implicaria, a longo prazo, taxa de lucro zero. Deste modo, é plausível supor em países de renda baixa e média a existência de uma relação não linear entre aumento de salários e crescimento econômico, de modo que há certo nível da parcela de salários na renda nacional que gera maior crescimento; todavia, a partir de algum limiar, o crescimento fica estagnado ou desacelera (possivelmente em decorrência do fenômeno de "profit squeeze", que possa levar a um congelamento no crescimento do estoque de capital).

Por isso, a melhor forma de defini-lo é como "estratégia" (Lavoie; Stockhammer, 2012), esperando-se que a elevação dos salários impacte positivamente sobre o consumo e o investimento, cuja articulação assegurará o crescimento da demanda agregada Dutt, 1987; Rowthorn, 1981; Taylor, 1983). Enquanto o impacto no consumo é mais ou menos imediato ou fortemente esperado (supondo-se, à la Kalecki, alta propensão a consumir dos trabalhadores), o desafio do regime wage-led growth é como criar uma relação virtuosa desse com o investimento, ao mesmo tempo em que se busca criar condições para um crescimento que não seja limitado pela restrição externa.

A definição da taxa de câmbio é aspecto essencial na distinção dos regimes de crescimento. Um regime profit-led growth (ou sua variante, export- 
-led growth), em uma economia aberta,exigiria câmbio desvalorizado, cujo reflexo de curto prazo, entre outros, é a redução real dos salários, ${ }^{7}$ fundamental para dinamizar a competitividade das exportações em setores tradables, o que acena para uma distribuição de renda mais favorável aos lucros do que aos salários (Blecker, 2010; Bresser-Pereira, 2012). ${ }^{8}$ Por sua vez, um regime wage-led growth exigiria câmbio relativamente valorizado e salários crescentes, mas possivelmente incidiria negativamente no equilíbrio da balança comercial e das transações correntes, dadas as características da existência de uma estrutura produtiva pouco diversificada e de baixa intensidade tecnológica, como é o caso da maioria dos países em desenvolvimento (Araujo; Gala, 2012).

\section{Estratégias de desenvolvimento no Brasil}

Diferentemente do desenvolvimentismo brasileiro dos anos 1950 aos 1970, a peculiaridade do crescimento recente, anos 2000, é que este foi acompanhado por melhora na distribuição de renda e tem como um dos seus drivers o crescimento do mercado interno (consumo), puxado pelo aumento na renda real e do crédito bancário. Isso levanta a questão se estaríamos diante de um crescimento puxado pelo consumo final ou de um caso típico de wage-led growth. De fato, vários fatores contribuíram para que o consumo das famílias fosse dinâmico entre 2000 e 2014: (a) a manutenção de taxas relativamente baixas de inflação, que tornou possível romper com o mecanismo de corrosão real dos salários, cuja indexação geral de preços e salários não conseguia evitar; (b) a recuperação do poder de compra do salário mínimo, que aumentou 934,0\% entre 1995 e 2014, muito acima da taxa de inflação acumulada, de 295,9\% (em termos reais, o salário mínimo cresceu 161,1\%); e (c) as transferências governamentais, cujos programas voltados às faixas de mais baixa renda, tais como o Programa Bolsa Família, além dos efeitos do aumento do salário mínimo sobre gastos previdenciários, foram expandidos.

7 Esses poderão ser gradualmente crescentes em longo prazo acompanhando o próprio crescimento econômico e as políticas moderadamente distributivas.

8 Não é demais ressaltar que a queda dos salários reais decorrente da desvalorização cambial está relacionada ao pass-through da taxa de câmbio para os índices de inflação. Para mais detalhes sobre tais efeitos na economia brasileira, ver: Arestis; Paula; Ferrari Filho (2009). 


\section{Gráfico 1 Wage share no Brasil (a preços de 2012)*}

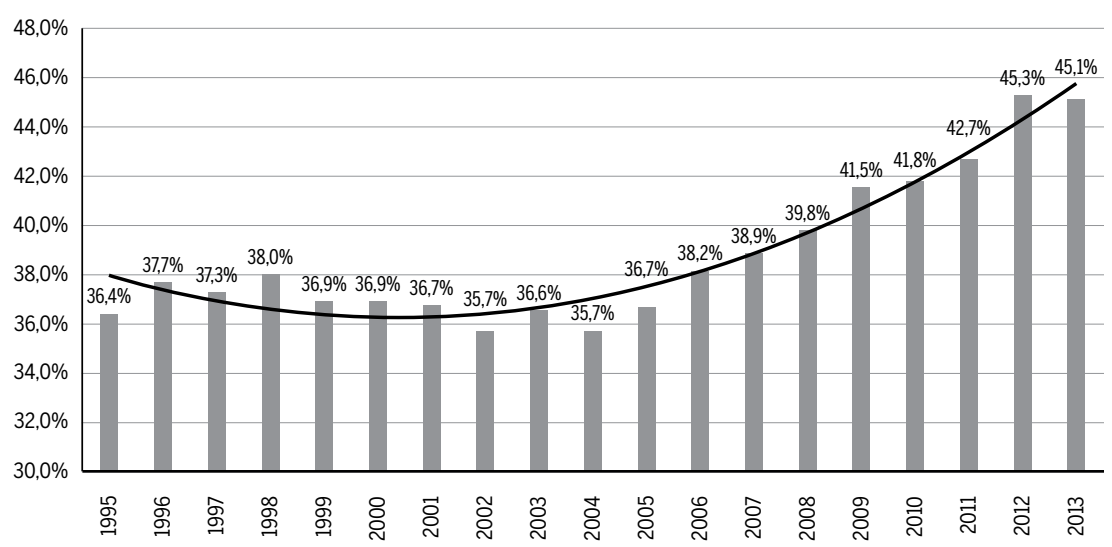

Fonte: IPEADATA (2015) e IBGE (2015).

${ }^{*}$ ) Massa salarial (deflacionada pelo INPC) dividido pelo PIB (deflacionado pelo deflator implícito).

Como pode ser visto no Gráfico 1, a participação da massa salarial na renda nacional, relativamente estável ao redor de 37\% em 1995/2001, caiu em $2002 / 2005$ para a média de $36,1 \%$, e cresceu acentuadamente a partir de 2005, vindo a atingir mais de $45 \%$ em 2012/2013, ainda que mostrando certa tendência a estabilidade dessa razão em 2013. ${ }^{9}$ É possível inferir o comportamento do profit-share por "um menos o wage-share". Há, portanto, clara tendência de aumento da participação de salários na renda no período 2006/2012, em função do aumento dos salários acima da elevação da produtividade do trabalho, o que sugere a prevalência no período de um regime wage-led.$^{10}$ Como pode ser observado no Gráfico 2 , o consumo final (cuja participação no PIB é de cerca de $80 \%$ ) foi no período a variável da demanda agregada que mais contribuiu para o crescimento no período

9 O cálculo do wage-share é feito do seguinte modo: WS $=W / Y$, onde W é a massa salarial real (deflacionada pelo IPCA), e Y é o PIB real (deflacionado pelo deflator implícito). A massa salarial é calculada da seguinte forma: $\mathrm{W}=\mathrm{RW} . \mathrm{N}$, onde $\mathrm{N}=$ nível geral de emprego (população ocupada menos percentual correspondente à participação dos empregadores); RW = salário médio real (rendimento médio dos empregados e dos autônomos). Dados extraídos do IPEADATA (2015) e IBGE (2015).

10 Bruno (2003), estimando funções de investimento, poupança e exportação, encontrou resultados que sugerem que o padrão de crescimento da economia brasileira entre 1973 e 1979 era do tipo profit-led, enquanto que, no período entre 1981 e 2000, era do tipo wage-led; já Araújo e Gala (2012) encontram, para o período 2002-2008, incluindo a participação do setor externo, que o regime da economia brasileira pode ser classificado como profit-led. 
2013-2014: sua variação percentual acumulada no período foi de 136,2\% (média de 11,4\% a.a.), enquanto a do investimento foi de 35,1\% (média de $2,9 \%$ a.a.), e as exportações foram de $9,5 \%$ (média de $0,8 \%$ a.a.).

\section{Gráfico 2 Contribuição no crescimento do PIB (variação percentual)}

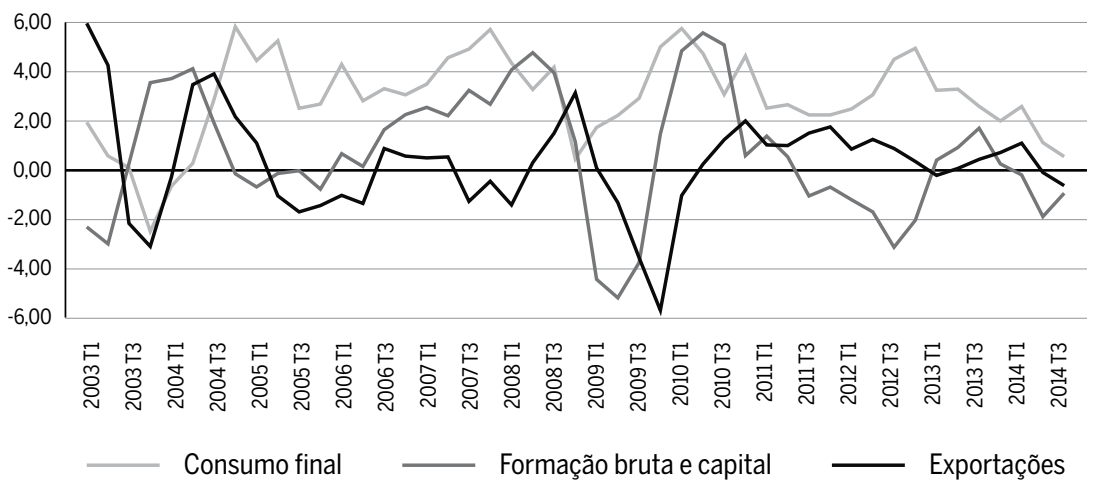

Fonte: IPEADATA (2015).

${ }^{*}$ ) Contribuição no crescimento do PIB no trimestre em relação ao mesmo trimestre do ano anterior.

As críticas a esse padrão de crescimento (puxado pelo consumo) partiram não somente da ortodoxia, que tradicionalmente o associam a "populismo econômico", mas também de outros economistas que apontaram as limitações desse "modelo" de crescimento, particularmente em razão da inconsistência de crescer com base na demanda doméstica, combinado com um processo de forte apreciação cambial, ocorrido durante a vigência do Plano Real (1994-1998) e posteriormente no período pós-crise de confiança, em 2002-2003, o que fez com que os estímulos ao crescimento vazassem para o exterior, levando a indústria nacional a perder posição na composição setorial do PIB.Para os economistas identificados pelo que foi denominado de novo-desenvolvimentismo (Bresser-Pereira, 2006, 2010, 2012; Bresser-Pereira; Gala, 2010; Oreiro; Paula, 2007; Oreiro, 2012), o processo de "desindustrialização" tem como principal variável explicativa a valorização cambial no período pós-Plano Real.

Nesta perspectiva, o crescimento liderado pela demanda doméstica somente foi possível em um contexto no qual: (a) os salários vinham de um histórico de crescimento abaixo da produtividade, de modo que havia certa "folga" para subir; e (b) a conjuntura externa era atipicamente favo- 
rável, seja pelos ingressos autônomos na conta capital, seja pelos superávits nas transações correntes, em face da liderança da demanda chinesa por commodities que impactou nos preços e nas quantidades exportadas pelo Brasil. Ademais, esse aumento da capacidade de importar teria permitido excepcionalmente o crescimento da demanda doméstica sem enfrentar um problema de restrição externa ao crescimento, mas seria um modelo de desenvolvimento inconsistente no longo prazo, uma vez que os estímulos de um consumo maior estariam "vazando" para o exterior, graças a uma taxa de câmbio apreciada. Diante desse contexto, a alternativa proposta aponta para um regime de crescimento à la export-led growth, em que a manutenção de uma taxa de câmbio competitiva assume o status de variável-chave na condução da política econômica, posto que as restrições ao crescimento decorrem tanto da "doença holandesa" quanto do excessivo influxo de capitais, que acabam apreciando a taxa real de câmbio, cujas consequências são o desequilíbrio do balanço de pagamentos e o desincentivo ao aumento da capacidade produtiva e de investimentos em setores comercializáveis. ${ }^{11}$ Nessa estratégia, o orçamento público deve estar rigorosamente equilibrado em longo prazo, ainda que em curto prazo possa ser usado de forma contracíclica, ao passo que o regime de metas de inflação deve ser mantido, ainda que flexibilizado (Bresser-Pereira; Oreiro; Marconi, 2015; Oreiro, 2012).

Por outro lado, outros autores (Bastos, 2012; Carneiro, 2012; Bielchowsky, 2012) entendem que o crescimento econômico deve ser dinamizado pelo mercado interno de massas, "que será quanto mais amplo quanto melhor vier a ser a distribuição de renda", e ainda, pelas "perspectivas favoráveis quanto a demanda estatal e privada por investimentos em infraestrutura (econômica e social)" (Bielchowsky, 2012, p. 730). O crescimento seria, portanto, baseado tanto na melhoria da distribuição pessoal quanto na da funcional da renda. ${ }^{12}$ Em particular, o crescimento de "mercado interno de massas" estaria sendo estimulado tanto pela expan-

11 Bresser-Pereira; Oreiro; Marconi (2015) sustentam que o crescimento puxado pelas exportações deveria ser utilizado apenas no período do catching up, uma vez que, vencida a fase de decolagem, o crescimento passaria a ser determinado pelo crescimento do demanda doméstica.

12 Carneiro (2012, p.775) ressalta, contudo, que "há também limites para a melhoria da distribuição funcional e pessoal da renda, que esbarram nas margens de lucro das empresas. Isso significa que, passados os momentos iniciais de redistribuição, essa se tornaria estável com as transferências de ganhos de produtividade aos salários e melhorias adicionais [que] só poderiam advir da ação do Estado via tributação e gasto público". 
são do nível de emprego quanto pela distribuição de renda, decorrente das políticas redistributivas do governo, tais como aumento real dos salários, em especial do salário mínimo, ampliação do gasto social (aumentos de recursos para as transferências previdenciárias e o Programa Bolsa Família) e inovações financeiras na área do crédito (crédito consignado e microcrédito). Em relação à expansão do crédito, esse é fundamental para sustentar a expansão do referido consumo. Ademais, ele deve estar direcionado não somente para o curto prazo, mas também para o financiamento de longo prazo do setor produtivo, que não pode prescindir do sistema financeiro estatal. Num segundo momento, dado que a estratégia de crescimento baseado no consumo de massas perde impulso com o passar do tempo, a expansão teria de ser completada ou secundada pelo investimento autônomo, ou seja, pelos investimentos públicos em infraestrutura econômica e social (Carneiro, 2012, p.775).

Essa estratégia de desenvolvimento, que vem sendo denominada social-desenvolvimentismo, sustenta políticas fiscal e monetária ativas, e é de forma geral simpática à política adotada nos governos Lula da Silva e no $1^{\circ}$ governo Dilma Rousseff. Em relação à taxa de câmbio, contrariamente ao novo-desenvolvimentismo, argumenta-se que esse deve se manter em níveis apreciados, o que facilitaria tanto a importação de bens de capital, seja para que o capital nacional absorva o progresso tecnológico em curso, seja para reduzir os custos finais de produtos comercializáveis, quanto evitaria a queda dos salários. A restrição externa seria atenuada pelo crescimento das exportações induzido pelo crescimento de escalas e capacitações propiciadas pelo mercado interno, dada a complementaridade entre mercado interno e externo, bem como pela expansão do setor intensivo em recursos naturais e suas cadeias produtivas (Bastos, 2012; Carneiro, 2012; Bielchowsky, 2012). ${ }^{13}$

Um aspecto interessante a ser destacado nessas estratégias de crescimento é que ambas sustentam que o export-led growth ou o wage-led growth devem ter vigência transitória: para os novo-desenvolvimentistas, apenas

13 Segundo Bastos (2012, p.799), "a apreciação cambial e inflação baixa foram essenciais para a expansão do mercado de massas de bens de consumo e serviços urbanos, e serviram para baratear as importações nas quais se materializou, em parte, o investimento privado". Para superar a restrição externa ao crescimento, a ideia é que "considerando [a] estrutura da economia brasileira e o contexto atual da concorrência mundial, parece menos provável ter-se um crescimento globalmente puxado pelas exportações, do que eventual aumento das exportações industriais, induzido pelo crescimento de escalas e capacitações propiciadas pelo mercado interno" (Ibid., p.802). 
para a realização do "catching-up"; para os social-desenvolvimentistas, apenas para os momentos iniciais de um processo de redistribuição (funcional) de renda.

Diante do exposto, entendemos que a escolha entre uma estratégia de crescimento wage-led growth e profit-led growth (e sua variante, export-led growth) parece ser uma opção falsa para a economia e a sociedade brasileira. Por um lado, a economia brasileira dificilmente poderia adotar um caminho asiático de desenvolvimento, baseado na competitividade das exportações via salário baixo e câmbio fortemente depreciado. Por outro lado, não pode e não deve abrir mão de, mesmo tendo o mercado interno como motor do crescimento, desenvolver e manter um setor manufatureiro dinâmico, com capacidade de inserção no comércio internacional. A manutenção de um superávit comercial robusto, o que requer até a exportação de bens manufaturados de maior valor agregado, é condição necessária para a economia brasileira não esbarrar na restrição externa ao crescimento econômico à la Thirwall, e ter uma fonte complementar de crescimento.

Nesse sentido, a compatibilização e um "meio termo" entre as duas estratégias de crescimento parece ser, portanto, a mais adequada. Assim sendo, como será explorado na seção 4, um padrão de crescimento, alicerçado em políticas econômicas e reformas estrutural-institucionais, deve (i) buscar melhor distribuição de renda, (ii) induzir a expansão dos investimentos e (iii) formular políticas cambial e de comércio exterior capazes de evitar ou minimizar eventuais impactos negativos que possam prejudicar o equilíbrio no balanço de pagamentos (e criar fonte adicional de crescimento).

\section{Uma análise do boom de crescimento pós-2003 e da desaceleração econômica em 2011-2014}

A economia brasileira, desde o início dos anos 1980, tem tido um comportamento à la stop-and-go, alternando pequenos ciclos de crescimento com desacelerações econômicas, muitas vezes abruptas. Esse padrão de crescimento se reproduz ao longo dos anos 2000: em 2000, o PIB cresceu 4,3\%; entre 2001 e 2003, houve forte desaceleração (nesse período, o PIB cresceu a uma taxa média de 1,7\% ao ano); entre 2004 e 2008, a economia brasileira cresceu a uma média anual de 4,8\%; em 2009, houve recessão 
em razão do contágio da crise mundial; em 2010, a economia cresceu a ritmo "chinês", 7,6\%; e, finalmente entre2011 e 2014, o PIB novamente desacelerou (média de $2,2 \%$ ao ano).

É importante ressaltar que a recuperação econômica a partir de 2004 foi puxada, inicialmente, pelo boom de commodities e depois pelo aumento no consumo das famílias, graças ao maior estímulo ao crédito bancário (desconto em folha) e ao aumento da renda real das famílias, bem como pela expansão da taxa de investimento decorrente da implementação do Programa de Aceleração do Crescimento (PAC), em 2007.

Todavia, os efeitos da crise pós-Lehman Brothers foram acentuados sobre a economia brasileira, por causa da abrupta e forte reversão nos fluxos de capitais externos e da desaceleração no mercado de crédito doméstico, ocasionando, assim, forte desaceleração do consumo e, principalmente, dos investimentos. De fato, o contágio da crise do Lehman Brothers sobre a economia brasileira, a partir de setembro de 2008, foi bastante agudo e rápido: saída de capitais estrangeiros aplicados em bolsa; redução da oferta de crédito externo para bancos e firmas (inclusive exportadoras); aumento das remessas de lucros e dividendos por parte de subsidiárias de empresas multinacionais; retração do mercado de crédito doméstico; e "empoçamento" de liquidez no mercado interbancário. Ademais, a vulnerabilidade da economia brasileira agravou-se em função do uso especulativo de derivativos cambiais por parte de algumas empresas exportadoras que lucravam apostando na continuidade do processo de apreciação cambial.

O governo Lula da Silva respondeu com grande variedade de instrumentos, incluindo: medidas de reforço à liquidez do setor bancário (redução no compulsório e criação de incentivos para os grandes bancos comprarem as carteiras de créditos de pequenos bancos); linha temporária de crédito para as exportações; intervenções do Banco Central do Brasil (BCB) no mercado cambial (venda de US\$ 23 bilhões no último trimestre de 2008); estímulo à expansão do crédito por parte dos bancos públicos; redução do imposto sobre produtos industrializados (IPI) para automóveis, eletrodomésticos e produtos de construção; aumento do período de concessão do seguro-desemprego; e criação de um programa de construção de moradia popular ("Minha Casa, Minha Vida"). ${ }^{14}$

14 Para um detalhamento das medidas anticíclicas adotadas no Brasil, no período 2008-2009, ver: Barbosa Filho (2010). Para uma análise sobre o comportamento da economia brasileira ao contágio da crise de Lehman Brothers e à crise do Euro, ver: Paula; Modenesi; Pires (2015). 
A nota destoante foi a manutenção da taxa de juros elevada por parte do BCB na gestão Meirelles até inicio de 2009, contrastando com a política fiscal anticíclica e a política creditícia dos bancos públicos.

Assim, o governo agiu de forma rápida e sinalizou claramente o objetivo de adotar uma política anticíclica (fiscal, cambial e creditícia), em que pese, como visto, a manutenção por parte do BCB dos juros elevados até janeiro de 2009. Ou seja, o governo conseguiu evitar uma deterioração mais drástica das expectativas, logrando êxito na recuperação econômica a partir de meados de 2009. Em particular, o crescimento da formação bruta de capital fixo e do consumo contribuiu para a recuperação da economia no segundo semestre (Gráfico 2). Em resposta à retomada do crescimento, à restauração da confiança dos agentes e à ampliação do nível de utilização da capacidade instalada da indústria, o investimento cresceu de $17 \%$ do PIB $\left(1^{\circ}\right.$ trimestre de 2009) para 20,5\% no terceiro trimestre de 2010. As exportações, por sua vez, foram favorecidas pela forte melhora nos termos de troca, em razão principalmente da retomada da economia chinesa em 2009 (crescimento de 9,2\%) e da recuperação da economia mundial em 2010.

Cabe destacar que as referidas ações foram favorecidas por decisões tomadas no período anterior: a combinação da redução na dívida externa pública com a política de acumulação de reservas internacionais resultou em um saldo líquido credor do governo em moeda estrangeira. Assim, a forte desvalorização cambial que seguiu ao contágio ( $43 \%$ de setembro a dezembro de 2008) favoreceu, pela primeira vez, as finanças públicas, facilitando o uso de uma política fiscal anticíclica. Por outro lado, as medidas de estímulo ao consumo foram beneficiadas pelo ainda moderado nível de endividamento das famílias - a razão endividamento sobre renda acumulada nos últimos 12 meses era de $38 \%$ em outubro de 2008 .

O governo Dilma Rousseff foi marcado pela gradual piora no cenário internacional graças à crise do Euro, à fraca recuperação norte-americana e à desaceleração dos países emergentes - a taxa de crescimento médio da economia mundial caiu de 5,1\% em 2010 para 3,8\% em 2011, 3,3\% em 2012, 3,1\% em 2013e 3,1\% em 2014 (IMF, 2015). Do ponto de vista da condução da política econômica, destacaram-se mudanças no mix e nos instrumentos de política, com uso de medidas macroprudenciais monetárias e cambiais, forte redução na taxa Selic (de 12,5\%, em julho de 2011, para 7,5\%, em agosto de 2012) e - após a adoção de uma série de medidas regulatórias sobre os fluxos de capitais, inclusive sobre o mercado de de- 
rivativos - uma desvalorização cambial de 25\% (entre agosto de 2011 e maio de 2012).

Por causa do bom desempenho fiscal no primeiro semestre de 2011, o Ministério da Fazenda pode adotar medidas fiscais para estimular o setor industrial, combalido pela forte apreciação do câmbio e pela acirrada competição do mercado externo. O principal instrumento foi a isenção fiscal, incluindo a redução do IPI sobre bens de capital e a desoneração da folha de pagamento de setores intensivos em mão de obra, permitindo a mudança na cobrança da contribuição previdenciária de $20 \%$ sobre o salário por taxas de $1 \%$ (ou $2 \%$ ) sobre os lucros das firmas. No segundo trimestre de 2012, foram adotadas medidas adicionais no âmbito do "Plano Brasil Maior", tais como: a ampliação da desoneração da folha de pagamento para outros setores; a redução do IPI de alguns bens duráveis (automóveis, geladeiras, etc.); a postergação do recolhimento do PIS/Cofins; e a redução da alíquota de IOF sobre operações de crédito a pessoas físicas. Em 2013, algumas medidas de incentivos fiscais foram mantidas, porém, por um lado, o governo sinalizou um ligeiro ajuste fiscal, e, por outro lado, o BCB voltou a elevar a Selic, fechando o ano em 10\%.Em 2014, ao mesmo tempo em que o BCB manteve sua política de elevação gradual na taxa Selic, verificou-se tendência de deterioração fiscal -o déficit nominal passou de $3,25 \%$ do PIB em dezembro de 2013 para 6,71\% do PIB em dezembro de 2014, em função de um conjunto de fatores, que incluem queda das receitas tributárias (desonerações fiscais e efeitos da queda do PIB) e impacto dos juros sobre o custo financeiro da dívida pública.

A despeito das políticas contracíclicas, excetuando-se naturalmente a elevação da Selic, o crescimento econômico entre 2011 e 2014 desapontou: a média anual foi de $2,1 \%$. Ainda que todos os itens do gasto agregado tenham caído (Gráfico 2), o mau desempenho da formação bruta de capital fixo foi o que mais contribuiu para a desaceleração da economia.

O fraco desempenho da economia brasileira resultou de um conjunto de fatores externos e domésticos. Embora a situação econômica da zona do Euro agora não fosse disruptiva, a ameaça de piora na crise afetou a economia brasileira - principalmente pelo canal do comércio exterior, em razão da no preço de algumas commodities e da queda geral na demanda externa por produtos manufaturados, semimanufaturados e básicos. Além disso, as expectativas empresariais deterioraram-se drasticamente em função do risco de ocorrência de um "grande evento", possibilidade de derrocada do Euro. 


\section{Gráfico 3 Produção industrial (quantum) e vendas reais no varejo ampliado*} $(100=$ Jan./2003)

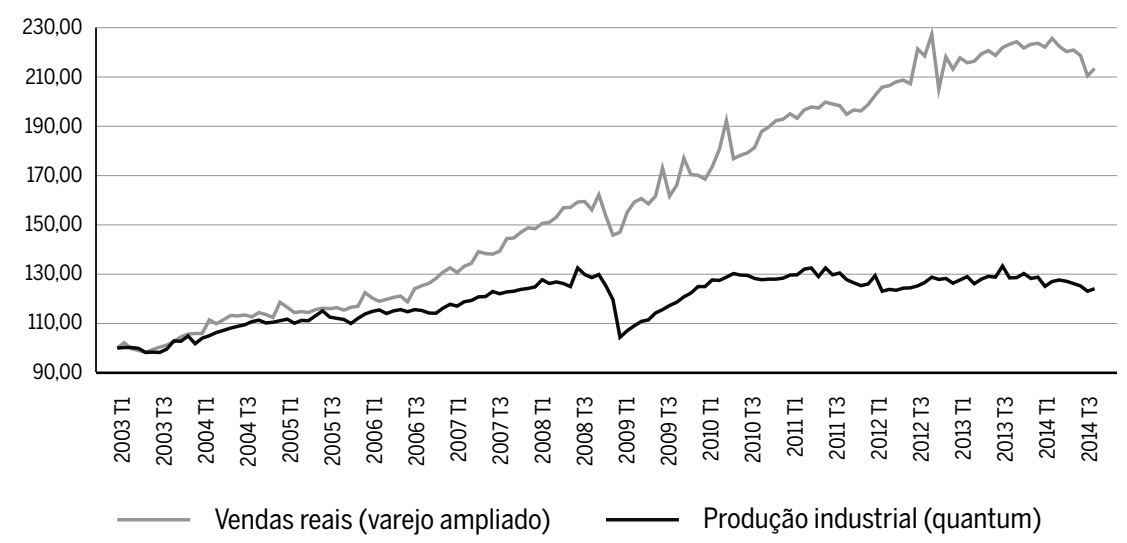

Fonte: IPEADATA (2015).

$\left.{ }^{*}\right)$ Inclui também as atividades materiais de construção e veículos, motos, partes e peças.

No lado doméstico, o produto industrial parou de crescer em consequência, principalmente, do aumento do coeficiente de importações, ou seja, valor das importações sobre o valor do produto doméstico do setor industrial. ${ }^{15}$ O quantum da produção industrial estagnou desde 2010, enquanto as vendas no comércio varejista continuaram aumentando até 2013, e em 2014 passou a reduzir num quadro de desaceleração econômica (Gráfico 3). Em outras palavras, os estímulos dados à demanda vazaram para o exterior, não beneficiando as empresas industriais domésticas, uma vez que essas não tiveram "acesso" a essa maior demanda. Consequentemente, a utilização de capacidade instalada da indústria diminuiu, ${ }^{16}$ gerando capacidade ociosa, que contribuiu para a desaceleração nos investimentos entre 2012 e 2014 -, já afetado pela deterioração nas expectativas empresariais em face da piora no cenário internacional.

As exportações declinaram 12,0\% em 2014, comparativamente a 2011, ao passo que as importações aumentaram $1,2 \%$ no mesmo período. Como consequência, o saldo comercial, ao longo desse período, foi reduzido de

15 Segundo dados da FUNCEX, o coeficiente de importações aumentou de $17,0 \%$, no $4^{\circ}$ trimestre de 2009, para 22,0\%, no $4^{\circ}$ trimestre de 2011, mantendo-se elevado desde então. 16 Em particular, a utilização da capacidade instalada da indústria caiu de $82,7 \%$, em junho de 2013, para 80,6\%, em junho de 2014, conforme dados do IPEADATA. 
US $\$ 29,8$ bilhões para - US $\$ 3,9$ bilhões. De fato, tanto os termos de troca quanto a demanda mundial declinaram em razão da desaceleração econômica mundial: os principais parceiros comerciais do Brasil (Europa, China, Estados Unidos e Argentina) tiveram crescimento declinante entre 2011 e 2014. As evidências empíricas de vários trabalhos acadêmicos, que procuraram estimar a função exportação para o Brasil, sugerem que o efeito preço (resultante do movimento da taxa de câmbio) é superado largamente pelo efeito renda mundial. ${ }^{17}$ Esse resultado ajuda a entender porque a desaceleração econômica mundial em 2012, por exemplo, anulou os efeitos positivos da desvalorização cambial sobre as exportações brasileiras.

Com relação às importações, deve-se considerar que anos seguidos de apreciação da taxa de câmbio (desde 2003) suscitou um comportamento defensivo das empresas (substituindo bens de capital e insumos por produtos importados), que não se altera imediatamente ao sabor dos acontecimentos - principalmente se considerarmos que uma desvalorização da ordem de $25 \%$ não foi suficiente para compensar a forte apreciação cambial acumulada desde 2004 .

Finalmente, a dinâmica dos gastos públicos - incluindo os investimentos públicos - não foi capaz de compensar a desaceleração geral dos outros componentes da demanda. O timing e a intensidade da resposta de política fiscal a partir do momento em que as crises financeiras internacionais e do Euro se iniciaram e foram bem diferentes. De fato, a política fiscal anticíclica em 2011 e 2012 foi muito limitada quando comparada ao período anterior. O superávit primário caiu imediatamente após o início da crise do Lehman Brothers. Durante a crise do Euro, ocorreu o inverso, e, apenas no décimo mês após o início da crise, verificou-se redução no superávit, de magnitude bem inferior à ocorrida na crise anterior (Gráfico 4).

Acrescente-se ainda que a composição da expansão fiscal limitou o seu efeito anticíclico. Durante a crise do Lehman Brothers, o governo deu mais ênfase às despesas, tais como: aumento do salário mínimo e das transferências sociais; aumento dos investimentos públicos e da Petrobras; e promoção do programa "Minha Casa, Minha Vida". Por sua vez, pelo lado das desonerações, as ações foram pontuais e temporárias, dentre as quais, a redução de impostos para veículos, eletrodomésticos e insumos da construção civil e a expansão das operações de crédito. Enquanto a resposta à 
crise do Lehman Brothers envolveu um conjunto rápido de desonerações fiscais importantes e de expansão de despesas, a resposta na crise do Euro ocorreu apenas a partir do $2^{\circ}$ semestre de 2012 , e enviesada na direção de desonerações fiscais, muitas das quais sem efeito claro sobre a atividade econômica. Os investimentos públicos representaram 1,1\% do PIB em 2012, valor equivalente ao de 2011 e menor do que o de 2010. Considerando-se o impulso fiscal como um todo, é possível concluir que ele foi muito menor, atrasado e com uma composição que resultou em impacto pouco significativo sobre a atividade econômica em 2011 e 2012 (em relação a 2009 e 2010).

\section{Gráfico 4 Superávit primário fiscal como percentagem do PIB (em meses)}

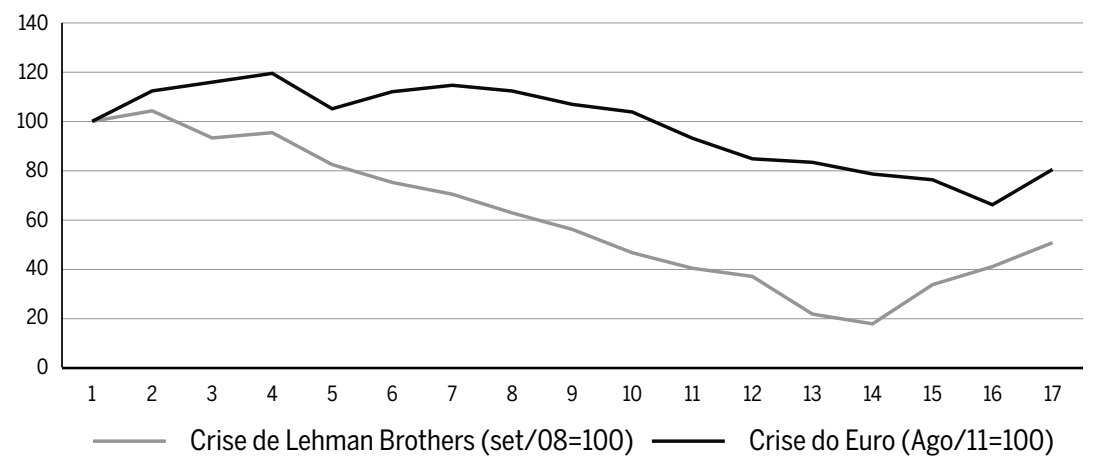

Fonte: Secretaria do Tesouro Nacional in Paula, Modenesi e Pires (2015, p.429).

Não é demais enfatizar que, entre 2010 e 2012, o governo apostou que a mudança no mix de política econômica (redução da Selic e desvalorização cambial) - a chamada "nova matriz econômica"-, somada às isenções fiscais, seria suficiente para impulsionar conjuntamente oferta e demanda agregada de bens, resultando em um crescimento econômico mais robusto. Quando ficou claro que não seria o caso, o governo procurou implementar medidas ad hoc para estimular o crescimento, como a extensão da desoneração de folha de pagamento para mais setores. Tal ação, contudo, não foi bem coordenada e careceu de consistência.

De fato, a adoção de uma política fiscal anticíclica em 2011 e 2012 se justificava em face do baixo desempenho da economia, mas essa veio atrasada e privilegiou isenções fiscais em vez de investimentos públicos. Para completar, não foi comunicada aos agentes de forma adequada: o governo pro- 
meteu, até o final do ano, que cumpriria integralmente a meta de superávit primário, acabando por utilizar artifícios contábeis para alcançar a meta. Melhor seria se, já em meados de 2012, o governo revisse realisticamente a meta quando estava claro que não iria conseguir cumpri-la, justificando tal mudança, como fez em 2009, em função da desaceleração em curso.

Em 2013 e, especialmente em 2014, a política monetária voltou a ser restritiva, bem como o governo começou a ser mais cauteloso nas políticas de incentivos fiscais, uma vez que a inflação passou a distanciar-se do centro da meta, 4,5\%: em 2010, 2011 e 2012, a inflação foi, respectivamente, $5,91 \%, 6,5 \%$ e 5,84\%. A ortodoxia monetária e fiscal, todavia, não resultou no arrefecimento da inflação, que fechou os anos de 2013 e 2014 em $5,91 \%$ e $6,41 \%$, respectivamente.

Enfim, parece haver evidências de que o baixo crescimento da economia brasileira e a desaceleração recente resultam da combinação de fatores conjunturais - piora no cenário internacional (redução de preços de commodities, por exemplo) e má coordenação de políticas macroeconômica a partir de 2010 - com fatores estruturais, incluindo o processo de desindustrialização em curso na economia brasileira (dados os efeitos de encadeamento que o setor manufatureiro tem sobre a economia como um todo). Ademais, contribui para o baixo crescimento um certo esgotamento do ciclo de expansão de consumo das famílias, por causa de: aumento no endividamento das famílias em relação à renda acumulada dos últimos doze meses - de 32,6\% em janeiro de 2009 para 46,0\% em final de 2014; redução na taxa de crescimento da oferta de crédito bancário (de mais de $20 \%$ até julho de 2011 para menos de $17 \%$ a partir de setembro de 2012), ${ }^{18}$ em parte em função dos efeitos defasados das medidas macroprudenciais adotadas no $1^{\circ}$ semestre de 2011, e, posteriormente,como resultado dos efeitos da elevação da taxa de juros a partir de meados de 2013 sobre a demanda por crédito; e ainda da própria desaceleração do crescimento dos salários a partir de 2013 (Gráfico 1).

Por fim, a desaceleração do setor industrial, setor com forte poder de encadeamento para trás e para a frente na economia, bem como portador de progresso técnico (portanto, mais capital intensivo), acabou por contribuir para a baixa taxa de investimento da economia, inviabilizando, assim, um crescimento econômico mais robusto e sustentável. 


\section{Uma proposição keynesiano-institucionalista para a economia brasileira}

Como mostraram as seções anteriores, a economia brasileira não pode prescindir de um regime de crescimento que tenha como dinâmica tanto a absorção do mercado interno quanto a expansão do setor externo. Além do mais, a volatilidade e a instabilidade do investimento foi um dos fatores determinantes da desaceleração da economia, principalmente após o contágio da crise financeira internacional e a grande recessão que a seguiu. Alguns autores, como Bielschowsky (2012), sustentam haver complementaridade entre crescimento do mercado doméstico e das exportações.

É possível argumentar que as diversas mudanças institucionais ocorridas na economia brasileira desde os anos 1990 acabaram por repercutir diretamente sobre o ambiente institucional e, com isso, poderiam contribuir para o processo de crescimento econômico sustentável; porém, elas acabaram comprometendo o referido crescimento, principalmente porque ele se caracterizou por uma dinâmica à la stop-and-go: o crescimento econômico não apenas tem sido baixo, como também volátil nas últimas décadas, ainda que haja um recente processo de melhoria na distribuição de renda no país. Dentre as mudanças mais significativas, podemos citar: a abertura externa e financeira do início dos anos 1990, que estabeleceu a necessidade de novos padrões de competitividade tanto externos quanto internos e reconectou a economia brasileira ao mercado financeiro internacional; a mudança do regime monetário com o Plano Real, que mudou as regras de convivência com a inflação; um novo desenho do Estado nacional, que passou a orientar-se muito mais por estratégias neoliberais do que por ações "desenvolvimentistas", então caracterizadas como obsoletas, retrógradas e anacrônicas; e uma orientação ortodoxa da política econômica, como antídoto às aspirações de retorno inflacionário. ${ }^{19}$

Com isso quer-se argumentar que dois aspectos decorrem de tais estratégias. Primeiro, as mudanças "institucionais" observadas com o Plano Real não foram literalmente embedded pelos agentes econômicos, impossibilitando, assim, a criação de um ambiente institucional favorável ao investimento. E, segundo, a política macroeconômica implementada ao longo desse período, principalmente alicerçada no Novo Consenso Macroeconô$19 \bigcirc$ que se segue retoma análises desenvolvidas em Ferrari Filho; Fonseca (2015) e Paula (2013). 
mico (NCM), qual seja, regime de metas de inflação e de superávit fiscal juntamente com câmbio flexível, limita um exercício mais autônomo das políticas monetária e fiscal e, por conseguinte, seu impacto sobre o PIB. Em suma, entre 1995 e 2014, as condições institucionais e macroeconômicas não despertaram o animal spirits dos empreendedores.

Diante desse quadro, pergunta-se: o que fazer para que a economia brasileira possa, efetivamente, alcançar um quadro de maior estabilidade macroeconômica, em um regime de inclusão social e distribuição de renda, mas que não se descuide da restrição externa ao crescimento?

Antes de respondermos à referida pergunta, é importante se ter ciência de que a economia brasileira apresenta algumas restrições históricas ao crescimento, quais sejam: por não ter, assim como outras economias emergentes, uma moeda de conversibilidade internacional, recorrentemente os desequilíbrios externos crônicos acabam gerando crises cambiais; existem gargalos de capacidade produtiva, como de infraestrutura, que limitam a expansão da demanda agregada; o sistema de financiamento da atividade econômica, principalmente de longo prazo, depende essencialmente do setor público; e a distribuição de renda, apesar da melhora ao longo da década de 2000, ainda é muito desigual. Neste sentido, a questão crucial é: como compatibilizar um crescimento econômico sustentado com equidade social?

Partimos do entendimento segundo o qual, em termos macroeconômicos, é necessário expandir a relação formação bruta de capital/PIB dos atuais $19 \%$ para $25 \%$, para termos um crescimento ao redor de $4,5 \%$ ao ano. ${ }^{20}$ Ademais, são necessárias mudanças estrutural-institucionais para expandir a demanda efetiva e a capacidade produtiva da economia. Em suma, devem ser criadas condições favoráveis para despertar, definitivamente, o animal spirits dos empresários.

No que diz respeito à estabilização macroeconômica, nos termos anteriormente defendidos, a ideia é que sejam criadas as condições favoráveis de promoção do pleno emprego e da recuperação do investimento, sinali-

20 Por que $25 \%$ ? Primeiro, porque, durante os anos 1970, período no qual o crescimento econômico brasileiro alcançou as maiores taxas de sua história, a relação formação bruta de capital/PIB era ao redor de $25 \%$; segundo, porque a taxa média da relação formação bruta de capital/PIB dos principais países emergentes é da ordem de $25 \%$ (média calculada pelos autores com base nos dados estatísticos do IMF (2015); e terceiro, porque Oreiro e Paula (2007) estimaram, baseados no modelo Harrod-Domar, que a relação formação bruta de capital/PIB deve ser da ordem de $27 \%$ para que o PIB brasileiro tenha crescimento próximo a $5 \%$ ao ano. 
zando políticas que deem suporte à demanda agregada. Nesse particular, as políticas monetária, fiscal e cambial devem ser adotadas de modo a fortalecer as decisões de investimento dos empresários, influenciando as expectativas de que seus lucros acumulados vão aumentar.

Mais especificamente, a política monetária deve ter como objetivo a estabilidade de preços e as metas de emprego, bem como a política fiscal deve ser articulada para permitir uma expansão no investimento público, em vez de se voltar simplesmente para cobrir o serviço da dívida e/ou o gasto corrente.

Políticas monetárias podem ser reorientadas, e o BCB deveria ter comprometimento com objetivos de emprego e inflação. Em outras palavras, ao $\mathrm{BCB}$ deve ser dado um mandato mais amplo que a presente concentração única na estabilidade de preços. Não há nada de revolucionário nisso. Essa é a estrutura de política monetária adotada pelo FED dos Estados Unidos, e em outros países. Evidentemente isso não ocorre sem problemas, mas evita a monolítica concentração sobre a estabilidade de preços, que não parece ter sido aplicada na história da humanidade com sucesso evidente. Ademais, deve-se avaliar a pertinência de se adotar medidas macroprudenciais para mitigar riscos financeiros e de uma expansão desenfreada do crédito.

A política fiscal, por sua vez, não deve ser colocada simplesmente para garantir o serviço da dívida pública a qualquer preço. Alguma combinação entre juros baixos e controle sobre o gasto corrente em longo prazo pode ser necessário de modo a aumentar o investimento público em infraestrutura econômica e social no Brasil. Neste sentido, a redução no superávit primário deveria ser usada para aumentar o investimento público, que tem efeito multiplicador maior sobre o crescimento da renda na economia. ${ }^{21} \mathrm{O}$ investimento público, ademais, é complementar ao investimento privado, contribuindo para o crescimento deste. É importante destacar que a redução na razão dívida pública sobre o PIB pode ser obtida com níveis razoáveis de superávit primário (digamos $2 \%$ do PIB), se combinado com uma redução na taxa de juros e um aumento no crescimento do PIB (que resul-

21 Castelo Branco; Lima; Paula (2015), ao avaliarem empiricamente o comportamento dos multiplicadores fiscais no Brasil em 1999-2012, como uso da metodologia VAR Estrutural bayesiano com mudança de regimes markovianos (MS-SBVAR), encontraram que os multiplicadores fiscais da formação bruta de capital fixo da administração pública são eficazes, tendo impacto de longo prazo no PIB e apresentando valores maiores no período de maior estabilidade econômica, em contraste com os multiplicadores fiscais do consumo da administração pública e da carga tributária líquida ineficazes (menores do que um). 
taria da combinação da queda na taxa de juros, desvalorização cambial e investimento público). A redução nessa razão poderia contribuir para alcançar o objetivo de longo prazo de equilíbrio fiscal, tal que as políticas fiscais pudessem ser operadas como um instrumento anticíclico. ${ }^{22}$

Enfim, a compatibilização entre uma desejada flexibilidade na política fiscal com a garantia das condições de sustentabilidade da dívida pública em longo prazo pode ser obtida pela divisão do orçamento público em dois segmentos distintos: (i) orçamento ordinário, relacionado às despesas correntes; e (ii) orçamento de capital, relacionado às despesas de investimento público. O orçamento ordinário deveria estar sempre em equilíbrio ou preferencialmente superavitário, ao passo que o orçamento de capital estaria provisoriamente em desequilíbrio, de modo a viabilizar os investimentos públicos em infraestrutura ${ }^{23}$ e nas áreas sociais (educação e saúde), que podem ter efeitos positivos tanto para o crescimento econômico como para a melhoria na distribuição de renda.

Um novo mix de políticas, entretanto, pode não ser bem-sucedido se o grau de conversibilidade da conta de capital for mantido, permitindo que residentes possam promover saídas de capitais facilmente em momentos de maior pressão especulativa, como pode ocorrer na estrutura de regulamentação dos fluxos de capitais. Por essa razão, a regulamentação nos fluxos de capitais através da adoção de controles baseados no mercado poderiam criar incentivos de mercado para reduzir os fluxos de capitais de curto prazo, de modo a preservar alguma autonomia das políticas econômicas domésticas.

Em consonância com a literatura empírica, o nível da taxa de câmbio (uma taxa de câmbio mais competitiva) é um dos fatores determinantes do crescimento da economia, em particular economias em processo de desenvolvimento, como a brasileira. Para tanto, a implementação de um regime de câmbio flutuante administrado, com vistas à manutenção de uma taxa

22 O nível requerido de superávit primário é determinado pela condição de solvência intertemporal do governo, ou seja: $s=\left[\frac{r-g}{1+g}\right] b$

em que $s$ é o superávit primário em relação ao PIB, $r$ é o nível da taxa real de juros, $g$ é a taxa de crescimento real do PIB, e $b$ é a razão dívida público sobre PIB.

23 Uma proposta a ser considerada é a apresentada por Silva; Pires (2006), que sugerem uma mudança na prática da política fiscal adotada no Brasil através de uma meta fiscal que exclua os investimentos públicos do cálculo do superávit primário, isto é, trocando o conceito de superávit primário pelo conceito de "poupança em conta corrente do governo", o que permitiria o governo aumentar os investimentos públicos. 
de câmbio real efetiva (TCRE) estável e competitiva, a fim de promover a lucratividade das atividades dos bens comercializáveis e prover incentivos para firmas investirem e expandirem a produção e o emprego, seria desejável (Frenkel, 2006). Uma taxa de câmbio competitiva é importante para evitar que estímulos ao crescimento do consumo acabem vazando para o exterior, como destacamos anteriormente. Ferrari Filho e Paula (2012) propõem a criação de um Fundo de Estabilização Cambial, a ser utilizado pelo Tesouro Nacional para comprar e vender divisas com vistas a influenciar a TCRE. Mas qual deve ser o valor da TCRE? As estimativas em relação ao nível da taxa de câmbio que estimule as exportações manufatureiras no Brasil $^{24}$ variam em funções de metodologias diferenciadas: Marconi (2012) calcula essa taxa em $R \$ 2,75$, enquanto estimativas mais recentes (Oreiro; Basílio; Souza, 2013) calculam em R \$3,26. Tal desvalorização cambial, entretanto, deve ser feita de forma gradual, buscando-se uma taxa de câmbio que não seja apreciada para criar desincentivos ao crescimento do setor industrial, mas tampouco muito desvalorizada para não reduzir bruscamente o poder de compra dos salários. De todo modo, como se pode concluir com base em Blecker (2009), uma desvalorização cambial será mais efetiva em seus efeitos expansionistas (exportações líquidas, maior crescimento, etc.), em um regime profit-led growth, o que, em termos de preceitos de política, pode sugerir que, para sua maior efetividade no Brasil, ela deveria ser conjugada com uma política de rendas que levasse a certa moderação salarial (isto é, que garantiria aumentos reais de salários moderadamente acima da produtividade).

Por fim, no que se refere à estabilidade de preços, faz-se necessário adotar uma política pragmática de combate à inflação, considerando que a inflação brasileira no período recente foi predominantemente uma inflação de custos. Um fator adicional importante no comportamento da inflação no Brasil é o fato de que a política de aumento real do salário mínimo tem tido impacto inflacionário, uma vez que pressiona duplamente a inflação de serviços, pelo lado da demanda, em função do aumento na renda de segmentos baixa-média de renda, e sobretudo pelo lado da oferta, em função dos efeitos de aumentos salariais, como no caso de comerciantes, domésticas, etc. Em outras palavras, uma parte importante da inflação é indústrias de bens comercializáveis utilizando a melhor tecnologia mundial e sem necessidade de subsídios. 
Bresser-Pereira (2010) intitula a "taxa de equilíbrio industrial" como aquela que viabiliza indústrias de bens comercializáveis utilizando a melhor tecnologia mundial e sem necessidade de subsídios. explicada pela melhoria na distribuição (funcional e pessoal) de renda no país, processo esse que não deve ser abortado, ainda que possa ser mais bem dosado. $O$ Gráfico 5 mostra que, desde 2005, a inflação de bens não comercializáveis tem superado a de bens comercializáveis (esses aumentam particularmente em momentos de maior desvalorização cambial).

\section{Gráfico 5 Taxa de inflação medida pelo IPCA (\% a.a.)}

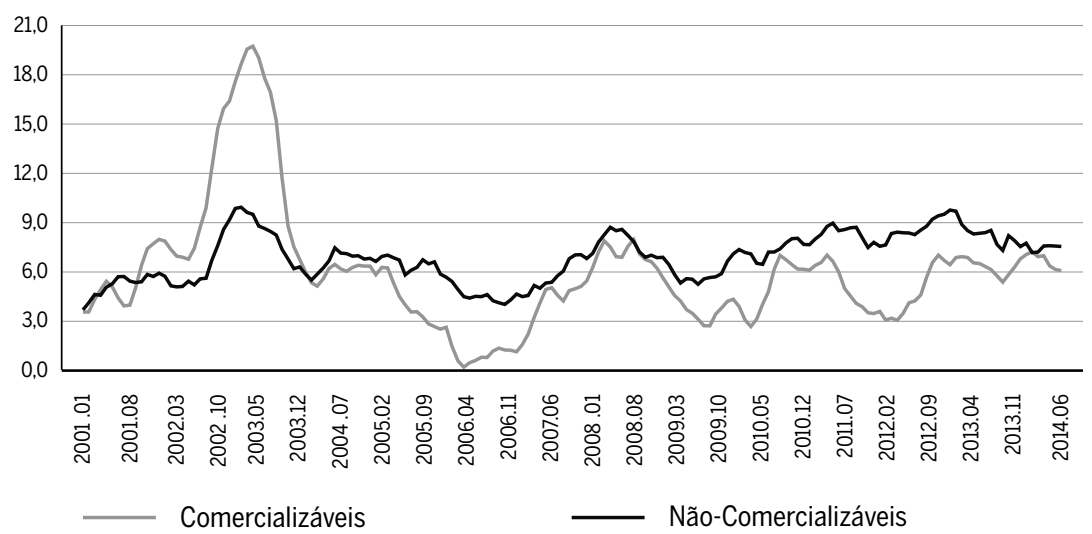

Fonte: IPEADATA (2015).

Ademais, outro componente importante da atual inflação brasileira é a indexação dos contratos. Nesse particular, eliminar a indexação dos preços, dos salários ${ }^{25}$ e dos ativos financeiros, especialmente aqueles vinculados às Letras Financeiras do Tesouro (LFTs), é fundamental para deixarmos a memória inflacionária para trás. Diante desses argumentos, em um contexto no qual o regime de metas de inflação seja mantido como regime monetário, é razoável que a meta de inflação não tenha níveis muito baixos, visto que isso implicaria ter de comprimir com taxas de juros muito elevadas os preços de bens comercializáveis, o que comprometeria o crescimento econômico. Assim deve se manter, em médio prazo, uma meta de inflação em $4,5 \%$ e suas bandas em $2 \%$. Por sua vez, cabe ressaltar que têm surgi25 Ressalta-se, contudo, que não estamos defendendo a desindexação do salário mínimo, já que esse tem de ser administrado pelo governo. 
do propostas interessantes que sugerem que a política monetária não seja operacionalizada unicamente em conformidade com o regime de metas de inflação, mas, sim, em um contexto que incorpore também metas de crescimento do PIB nominal. ${ }^{26}$

A estabilidade de preços, necessária para evitar uma deterioração do poder de compra do trabalhador, deve ser obtida com uma política ampla de combate à inflação, incluindo política de rendas (definição de regras de salário mínimo, negociação salarial em geral, etc.), revisão dos resquícios de indexação da economia, redefinição de regras de reajustes de preços administrados, como planos de saúde, que estimulem a redução de custos, etc. Portanto, a adoção de políticas de rendas é particularmente recomendada para estabelecer alguma âncora para os preços. A política fiscal (sem ser exageradamente contracionista) pode contribuir para manter preços sob controle por ocasião em que o governo venha a desvalorizar a taxa de câmbio a fim de atingir níveis mais competitivos para estimular as exportações líquidas, se contrapondo, assim, aos efeitos expansionistas de médio e longo prazos ocasionados pela própria desvalorização.

No que diz respeito às mudanças estrutural-institucionais, necessárias, segundo Hodgson (2002), para a sinalização de um "continuous process" de reestruturação do capitalismo para que esse não fique sempre dependente do mecanismo automático das "leis" de mercado, antes de tudo é necessária a redefinição do papel do Estado na economia, por meio da reconstrução dos mecanismos de coordenação desmontados ao longo dos anos 1990. Em outras palavras, o Estado tem de voltar a exercer suas funções de planejador, regulador e indutor da atividade econômica. Neste particular, é fundamental, como assinalou Evans (1993), dotar o Estado de uma burocracia meritocrática com autonomia inserida e estimular a existência de fóruns de articulação e consulta (redes externas) entre Estado e setor privado, de particular importância para a implementação e definição da política industrial. De fato, para expandir a capacidade produtiva e, por conseguinte, o PIB potencial,são necessárias políticas industriais ativas que coordenem esforços públicos e privados para alcançar uma taxa de acumulação de capital compatível à expansão da demanda agregada. Nesse sentido, é fundamental estabelecer uma sincronia das políticas macroeconô-

26 Segundo Summer (2014), metas de crescimento do PIB nominal levam a uma inflação razoavelmente baixa ao longo do tempo, bem como minimiza o ciclo econômico, tornando os momentos de aquecimento e desaquecimento da economia menos severos. 
micas com as mudanças tecnológicas oriundas da transição de paradigma tecnoeconômico à la Freeman e Perez (1988), tal qual estamos atravessando. De fato, como assinala Corden (1980), uma política industrial para ser bem-sucedida tem de estar bem coordenada com a política macroeconômica. ${ }^{27}$ Complementarmente, são imprescindíveis: (i) a operacionalização de uma política industrial com o objetivo de integrar a economia brasileira ao cenário internacional, o que permitiria criar um contexto no qual o Brasil poderia incorporar inovações tecnológicas em setores relevantes e ser capaz de atrair investimentos diretos estrangeiros que propiciassem adicionar valor às exportações; (ii) a introdução de iniciativas fiscais, tais como imposto de renda progressivo e continuidade a programas de renda mínima e gastos sociais, com o objetivo de aprimorar o padrão de vida das populações de baixa renda; e (iii) a implementação de uma política salarial com base em reajustes no salário mínimo que mantenha os ganhos reais nos salários (ainda que não exagerados).

\section{Conclusão}

As propostas apresentadas na seção anterior, com inspiração nas abordagens keynesiana e institucionalista, partiram do entendimento de que é importante aproveitar a oportunidade histórica de crescimento com melhor distribuição de renda da economia brasileira na última década para viabilizar no país um padrão de crescimento que concilie os regimes wage-led growth e export-led growth - ou seja, mantenha o crescimento da massa salarial sobre a renda nacional (enquanto não atingir um "ponto crítico" que possa comprometer o crescimento econômico, como visto na seção 2), ao mesmo tempo em que proporcione dinamismo para as exportações de modo a atenuar o problema de restrição externa ao crescimento e criar uma fonte adicional de crescimento econômico. Para tanto, estabelecemos,com base em Ferrari Filho e Fonseca (2013), a distinção entre variável desencadeadora e padrão de crescimento, tendo como corolário que o crescimento econômico, para lograr uma trajetória de longo prazo virtuosa, dependerá da articulação entre a variável desencadeada e os demais

27 No caso do Brasil, foi evidente que a implementação de uma política industrial no governo Lula da Silva, a partir de 2006, foi prejudicada com a política de juros elevados e câmbio apreciado. 
componentes da demanda agregada, principalmente o investimento. Esse padrão de crescimento, todavia, não se viabiliza espontaneamente; por isso, faz-se necessária a adoção de políticas desenvolvimentistas (econômicas e institucionais) voltadas a esse fim. As baixas taxas de crescimento dos últimos anos sugerem que o problema não está necessariamente na variável desencadeadora, mas justamente em articulá-la com as demais, de modo a fomentar um ambiente propício ao crescimento. Por outro lado, a volatilidade da política econômica permite inferir, da mesma forma, que não há estratégia de crescimento, ou seja, a política econômica emite sinais contraditórios, inconsistentes com um ou outro padrão. $\bigcirc$ pressuposto é que o crescimento do produto e do emprego depende da adoção de um mix de políticas macroeconômicas que crie um ambiente de estabilidade econômica necessário para estimular as decisões de investimento dos empresários. Neste sentido, uma boa coordenação entre as políticas monetária, fiscal e cambial é imprescindível para a eficácia da política econômica (Paula; Modenesi; Pires, 2015, seção 2).

Visando assegurar a estabilidade macroeconômica, as medidas aqui elencadas, embora não exaustivas, propõem-se a articular políticas em uma linha de convergência com os pensamentos keynesiano e institucionalista, a fim de estabelecer maior e mais explícita vinculação das convenções ou estratégias nacionais, a serem concebidas, com o avanço do processo de crescimento econômico, permitindo que seus frutos possam ser compartilhados pelos mais diferentes segmentos sociais, os quais precisam se ver representados na implementação de um Projeto Nacional para o país. Assim, o caráter macroeconômico do referido padrão articularia o ambiente institucional agregado com decisões individuais desagregadas, assegurando consistência sistêmica para um projeto desenvolvimentista. Em nossa visão, essa estratégia de novo padrão de crescimento procura preencher a lacuna deixada pelo processo de substituição de importações, qual seja, a melhora da distribuição de renda, agravada pelo baixo crescimento a partir da década de 1980, e superar a tendência recente de um padrão de crescimento à la stop-and-go. O objetivo é alcançar um crescimento econômico sustentável e robusto com equidade social. Para tanto, é fundamental, valendo-sedo instrumental teórico aqui exposto, viabilizar um desenvolvimentismo capaz de articular crescimento e distribuição com as necessidades de equilibrar o balanço de pagamentos, dadas as restrições externas da economia brasileira. 


\section{Referências}

ARAÚJO, E.; GALA, P. Regimes de crescimento no Brasil: evidências empíricas e implicações de política. Estudos Avançados, v. 26, n.75, p. 41-56, 2012.

ARESTIS, P.; PAULA, L. F.; FERRARI FILHO, F. A nova política monetária: uma análise do regime de metas de inflação no Brasil. Economia e Sociedade, 18, n¹ (35), p. 1-30, abril 2009.

BANCO CENTRAL DO BRASIL. Séries Temporais. Disponível em: <http://www.bcb.gov.br>. Acesso em: 2 maio 2015.

BARBOSA FILHO, N. Latin America: counter-cyclical policy in Brazil: 2008-09. Journal of Globalization and Development 1, n. 1, p. 1-12, 2010.

BASTOS, P. P. Z. A economia política do novo desenvolvimentismo e do social desenvolvimentismo. Economia e Sociedade, v. 21, n. especial, p. 779-810, 2012.

BHADURI. A.; MARGLIN, S.Unemployment and the real wage: the economic basis for contesting political ideologies. Cambridge Journal of Economics, v. 14, p. 375-393, 1990.

BIELSCHOWSKY, R. Estratégia de desenvolvimento e as três frentes de expansão no Brasil: um desenho conceitual. Economia e Sociedade, v. 21, n. especial, p.729-747, 2012.

BLECKER, R. International Competition, Income Distribution and Economic Growth. Cambridge Journal of Economics, v. 13, p. 395-412, 1989.

BLECKER, R. Open economy models of distribution and growth. Working Papers 2010-3. American University, Department of Economics, 2010.

BRESSER-PEREIRA, L.C. O novo desenvolvimentismo e a ortodoxia convencional. São Paulo em Perspectiva, v. 20, n. 3, p. 5-24, 2006.

BRESSER-PEREIRA, L. C. Globalização e competição. Rio de Janeiro: Campus/Elsevier, 2010.

BRESSER-PEREIRA, L. C. The new developmentalism as a Weberian ideal type. Paper in honor of Robert Frenkel, September, 2012. Disponível em: <http://www.bresserpereira.org.br>. Acesso em: 25 abril 2014.

BRESSER-PEREIRA, L. C.; GALA, P. Macroeconomia estruturalista do desenvolvimento. Revista de Economia Política, v. 30, n. 4, p. 663-686, 2010.

BRESSER-PEREIRA, L. C.; OREIRO, J. L.; MARCONI, N. Developmental Macroeconomics as a Growth Strategy. Abington: Routledge, 2015.

BRUNO, M. Regimes de crescimento, mudanças estruturais e distribuição na economia brasileira (1970-2001). In: ENCONTRO NACIONAL DE ECONOMIA POLÍTICA. 8., 2003, Florianópolis. Anais.... Florianópolis: SEP, junho 2003.

CARNEIRO, R. M. Velhos e novos desenvolvimentismos. Economia e Sociedade, v. 21, n. especial, p. 749-778, 2012.

CASTELO BRANCO, M. A.; LIMA, E. C. R.; PAULA, L. F. Mudanças de estado e multiplicadores fiscais no Brasil entre 1999-2012: Uma avaliação empírica, mimeo, 2015.

CORDEN, M. Relationships between macro-economic and industrial policies. The World Economy, v. 3, n. 2, p. 167-184, 1980.

DUTT, A. K. As relações de troca e o desenvolvimento desigual: resultados de um modelo de 
comércio Norte-Sul. Pesquisa e Planejamento Econômico, v. 17, n. 3, p. 533-559, dezembro 1987.

EVANS, P. O Estado como problema e solução. Lua Nova: Revista de Cultura e Política, p. 2829:107-157, 1993.

FERRARI FILHO, F; FONSECA, P.C. D.Which developmentalism? A Keynesian-Institutionalist wage-led proposal. Review of Keynesian Economics, v. 3, n. 1, p. 90-107, 2015.

FERRARI FILHO, F.; PAULA, L. F. Avaliação do regime cambial brasileiro pós-1999: análise crítica e prospectiva. In: OREIRO, J. L.; PAULA, L. F.; BASÍLIO, F. (Orgs.). Macroeconomia do Desenvolvimento: ensaios sobre restrição externa, financiamento e política macroeconômica. Recife: Editora da UFPE, p. 317-354, 2012.

FRENKEL, R. An alternative to inflation targeting in Latin America: macroeconomic policies focused on employment. Journal of Post Keynesian Economics, v. 28, n. 4, p. 573-591, 2006.

FONSECA, P.D.Desenvolvimentismo: a construção do conceito. In: CALIXTRE, A.; BIANCARELLI: A.; CINTRA, M. A. (Org.). Presente e Futuro do Desenvolvimento Brasileiro. Brasília: IPEA, p. 29-78, 2014.

FREEMAN, C.; PEREZ, C. Structural crises of adjustment business, cycles and investment behavior. In: DOSI, G.; FREEMAN, C.; NELSON, R.; SILVERBEG, G; SOETE, L. (eds.). Technical Change and Economic Theory. London: Pinter Publishers, 1988.

HEIN, E. Wage- and profit-led regimes. In King, J. (Ed.). The Elgar Companion to Post Keynesian Economics. 2.ed. Cheltenham: Edward Elgar, 2012.

HODGSON, G. M. The evolution of institutions: an agenda for the future theoretical research. Constitutional Political Economy, v. 13, p. 111-127, 2002.

IBGE. Indicadores. Disponível em: <http://www.ibge.gov.br>. Acesso em: 2 maio 2015.

IMF (INTERNATIONAL MONETARY FUND) Data and Statistics. Disponível em: <http:// www.imf.org>. Acesso em: 2 maio 2015.

IPEADATA. Séries Históricas. Disponível em: <http://www.ipeadata.gov.br>. Acesso em: 2 maio 2015.

KEYNES, J. M. The General Theory of Employment, Interest and Money. London: Palgrave Macmillan, 2007.

LAVOIE, M; STOCKHAMMER Wage-led growth: concept, theories and policies. Conditions of Work and Employment Series n41, International Labour Office, Geneva, 2012.

MARCONI. The industrial equilibrium exchange rate in Brazil: an estimation. Brazilian Journal of Political Economy, v. 32, n. 4, p. 656-669, 2012.

OREIRO, J.L. C. Novo-desenvolvimentismo, crescimento econômico e regimes de política macroeconômica. Estudos Avançados, v.26, n. 75, p. 29-40, 2012.

OREIRO, J.L.; BASÍLIO, F.; SOUZA, G. J. Acumulação de capital, taxa real de câmbio e catching-up: teoria e evidência para o caso brasileiro. In. FÓRUM DE ECONOMIA DA FGV/EESP, 10., 2013, São Paulo. São Paulo, outubro 2013.

OREIRO, J. L.; PAULA, L. F. Strategy for economic growth in Brazil: a post keynesian approach. In: ARESTIS, P.; BADDELEY, M; McCOMBIE, J.S.L (Eds.). Economic Growth: new directions in theory and policy. Edward Elgar: Alderhot, 2007. 
OREIRO, J. L.; PAULA, L. F. O novo-desenvolvimentismo e a agenda de reformas macroeconômicas para o crescimento sustentado com estabilidade de preços e equidade social. In: OREIRO, J. L.; PAULA, L. F.; Basilio, F. (Ed.). Macroeconomia do Desenvolvimento: Ensaios sobre restrição externa, financiamento e política macroeconômica. Recife: Editora da UFPE, 2012.

PAULA, L. F. Políticas macroeconômicas para um crescimento robusto e sustentável. In: FÓRUM DE ECONOMIA DA FGV/EESP, 10, 2013, São Paulo. São Paulo, outubro 2013.

PAULA, L.F.; MODENESI, A.; PIRES, M. C. The tale of the contagion of the two crisis and policy responses in Brazil. Journal of Post Keynesian Economics, v. 37, n. 3, p. 408-435, 2015.

RAZMI, A. Export-led growth. In: King, J. (Ed.). The Elgar Companion to Post Keynesian Economics. 2. ed. Cheltenham: Edward Elgar, 2013.

ROWTHORN, R. Demand, Real Wages and Economic Growth. London: North East London Polytechnic, 1981.

SCHETTINI, B.; SQUEFF, G.; GOUVÊA, R.Estimativas da função de exportações agregadas com dados das Contas Nacionais Trimestrais. Economia Aplicada, v. 16, n. 1, p. 167-196, janeiro-março, 2012.

SILVA, A. M.; PIRES, M. C. Dívida pública, poupança em conta corrente do governo e superávit primário: uma análise de sustentabilidade. Texto para Discussão IPEA, n 1196, junho, 2006.

SUMNER, S. B. Nominal GDP targeting: a simple rule to improve Fed performance. Cato Journal, v.34, n. 2, p. 315-337, Spring-Summer, 2014.

TAYLOR, L. Structuralist Macroeconomics: Applicable Models for the Third World. New York: Basic Books, 1983.

THIRLWALL, A. P. The Nature of Economic Growth. Cheltenham: Edgard Elgar, 2002.

\section{Sobre os autores}

Fernando Ferrari Filho-ferrari@ufrgs.br

Universidade Federal do Rio Grande do Sul, Porto Alegre, RS.

Luiz Fernando de Paula - luizfpaula@terra.com.br

Universidade do Estado do Rio de Janeiro, Rio de Janeiro, RJ.

\section{Sobre 0 artigo}

Recebido em 23 de outubro de 2014. Aprovado em 22 de julho de 2015. 